\title{
The Improvement Path of Ideological and Political Education in Colleges and Universities from the Perspective of Internet
}

\author{
Kaiwei He \\ Sichuan Vocational College of Information Technology, 628040
}

Key words: Internet; university; ideological and political education; improvement

\begin{abstract}
The ideological and political education in colleges and universities should be the focus of the work of colleges and universities, because the quality of ideological and political education work is related to the effectiveness of school campus construction directly, and it also related to the comprehensive development of students. But we can easily find that in the current colleges and universities, although there are some achievements in the ideological and political education, while there are more obvious drawbacks, coupled with the context of the Internet, the ideological and political work in colleges and universities are facing both opportunities and challenges, so as educators we must clearly understand the problems in our school of the ideological and political education, and use the advantages of the Internet to improve ideological and political education actively. This paper mainly analyzes the existing problems of ideological and political education in the Internet, and then puts forward some suggestions of the improvement measures of ideological and political education in colleges and universities.
\end{abstract}

\section{The Analysis of the Present Situation and Reasons of Ideological and Political Education in Colleges and Universities}

1.1 Teaching Concept Obsolete, do not Attach Enough Importance to Ideological and Political Education. One of the problems of school's educational philosophy or teaching concept is wrong. Colleges and universities should be the education base of students which provides a comprehensive development to students. In addition it also needs to ensure that students get good guidance of the professional ability, and we should pay attention to the overall quality of students training, which includes the ideological and political quality of students. But the school is affected by the traditional concept of education and teaching, it still cannot pay attention to the work of ideological and political education in the ideological, the main performance of the ideological and political education is that classes arranged very few and most of them are in the sophomore year, The teachers did not get regular training as professional teachers. Otherwise the students' attendance did not really catch up in the ideological and political classes. In addition, regardless of the school and the teacher, many of the students' ideological and political examination is only a mere formality, the assessment criteria are simple and basically do not exist the phenomenon that large number of students are failing the exam [1]. Of course, in addition to the problem of the school's teaching concept, students are also affected by the impact of traditional education, they think that the focus of school learning is only professional courses certainly, this ideological and political lessons cannot be on, the most important thing is to improve the professional class points. Therefore, there are a large number of students skipping, absenting or listening to the class halfheartedly.

1.2 Teachers Teaching in a Single Way, Students Lack Interest. In addition to lacking of the concept of emphasis on ideological and political education, teaching methods is also reflected on the teaching concept of fuzzy teaching led to a single way. The traditional way of ideological and political education is that the teacher has already prepared the courseware and then conveyed the knowledge of the books and the courseware to the students in the classroom. As for the student's feedback, or whether they understand this part of the knowledge is not known. And in the current ideological and political education in colleges and universities, some teachers because some teachers do not attach importance of the ideological and political and the students are not active in class, naturally that makes the teacher's class enthusiasm reduce, and even more some teachers do not ready the courseware just follows the book blackboard or directly read the book contents 
according to the book. How this boring and meaningless ideological and political lessons can attract students' interest? Students are not interested in ideological and political affairs, and a lot of tedious thinking of the theory is very offensive, if the teachers' attitude in the classroom is not serious, and lacking of passion, have no sense of humor, there is no initiative and the habit of interacting with students, so that students are more tired of ideological and political lessons.

\section{Opportunities and Challenges for Ideological and Political Education from the Perspective of Internet}

2.1 Opportunity. The development of the Internet to the ideological and political education in colleges and universities has brought great opportunities, these opportunities are mainly behaved like the two points. First, the Internet has a large amount of educational resources. The inclusion of the Internet is very strong, and its content involves all aspects of society, which bring a lot of teaching materials for the ideological and political education in colleges and universities[2]. For example, ideological and political educators can find high-level, highly representative cases of students from the Internet for multi-angle education, which provide an effective way to improve student interest, training students' values all-round. Second, the interactive and virtual nature of the new media in the Internet makes the school is not limited to the traditional teaching methods in the ideological and political education, you can use such as multimedia, audio and video and text combination, WeChat QQ platform to carry out the ideological and political education to students, which have a positive effect of broadening the ideological and political education channels, improving student interest, closing the relationship between teachers and students.

2.2 Challenge. The Internet is a double-edged sword, there is a positive side, naturally also a negative side, the opportunity brought by the Internet, thinking from another point, we will find these opportunities is a challenge actually. For example, because of the openness of the Internet and the richness of its content lead to ideological and political education more difficult to a certain extent,, because the information on the Internet is huge and complex, the ability of students to distinguish between good and bad is weak, educators feel difficult to filter the information, then they have a greater difficulty on the guidance of students. In addition, it is the new media interactive and virtual characters required to improve the requirements of teachers and students. Teachers are not only need to deep Marxist ideology and cultural accomplishment, but also need to use the skills of new media technology; students not only needed to good at using new media to innovate and diverge their thinking, but also need to have a strong media literacy.

\section{How to Improve Ideological and Political Education in Colleges and Universities under the Internet}

3.1 Make Full Use of the Massive Information of the Internet, Strengthen the Construction of Ideological and Political Education in Colleges and Universities. First of all, schools, teachers and students should pay enough attention to the ideological and political education, change the original concept of traditional education, realize that ideological and political education have a huge positive role for schools, teachers and students, develop ideological and political teaching objectives and teaching programs seriously, whether school teachers or students they all should pay attention to the attendance system and examination system of ideological and political affairs. Secondly, in the Internet perspective, we must fully understand the Internet to carry out a major impact on ideological and political education of the school, learn to use a lot of teaching resources on the Internet. For example, schools can collaborate with media organizations to transfer the latest hot news, ideas, and traditional culture to students through digital media and micro-news forums and communicate students in a timely manner with new media. In addition, due to the particularity of the Internet, schools can set up information network monitoring mechanism, mainly to filter the network information, stop the students to get the temptation of bad information, but also to strengthen the media literacy education [3], so that students can realize the pros and cons of new media, the correct use of new media. 
3.2 Improve the Teachers' Ability of using New Media, Carry Out the Ideological and Political Education in Multi-channel. First of all, the teacher must keep pace with the times, have a continuous improvement in self-professional ability and improve their comprehensive ability which including innovative teaching methods at the same time. For example, teachers should always pay attention to fresh current affairs, social hot issues, the topics that student groups concerning about, in order to attract students' interest in the classroom, they also can be more humorous in language expression, in the form of teaching content can be more close to the characteristics of some students. Second, teachers need to be familiar with the use of new media, such as mobile newspapers, forums, WeChat and so on. In addition, the teacher can combine new media and traditional education in the innovative teaching methods, such as the use of multimedia, video and textbooks together, raise students' discussion on the ideological and political aspects through the hot topics on the network. Of course, making full use of new media is also showed that teacher can use new media to communicate with students, such as through micro-credit groups, QQ group to discuss with students on a social problem and have a timely feedback on their learning and life problems, and enhance the relationship of students is also an important step in improving ideological and political education.

3.3 Use the Internet Reasonably, and Guide the Students in a Proper Way. Last but not least, it is that teachers and students need to take it seriously. First of all, college students have been ignorant of the age, it should also have a level of rational awareness. Online things true or false, we search for information, see video, chat to talk gossip, make friends rationally, they all do not matter, but must be cautious, they should have their own principles of adherence, cannot arbitrarily believe that online things need to be identified seriously, things that really cannot identify that they need to talk to their friends, and even can seek the school teacher or counselor's help. Second, the teacher as an educator, must be responsible for the students, no matter who is counselor or school teacher, they all should be taking care of every student in the humanism. Students may be more fragile psychological, which requires teachers to take the initiative step and get along with students well, appropriate humor and fun not only enhance the interest of students in class, but also left a better impression to the students, students are more willing to communicate with the teacher. The relationship between teachers and students are closer, it is more able for teachers to integrate into the student groups, to understand the students' ideas and their ubiquitous confusion, which has played a very good help to start the ideological and political work. Teachers also need to understand and use the Internet, know the current trend, in order to understand the mentality of students and face their own work with a young and positive attitude, after understanding the network, it is possible to use the network of students to do the ideological-political work, and give them the right guide.

\section{Conclusion}

Thinking from the overall aspect in the current situation that the ideological and political education of colleges and universities is not optimistic, mainly because of the traditional education concepts and education system, schools, teachers and students are not break through the shackles of the traditional model really. The lack of attention to education is the main reason for the above phenomenon. In the background of the Internet, the ideological and political education in colleges and universities ushered in new opportunities, of course, there are challenges, but as educators we need to use the good side of the Internet to develop the ideological and political education actively, broaden the teaching resources, innovative the teaching methods.

\section{References}

[1] Yi Lu, Lu Xin, Song Daiyue.[J] .Journal of Ideological \& Politics and Law, 2016 (11): 87-88 (in Chinese with English abstract). [J] .Journal of Ideological and Political Science, 2016 (11): 87-88.

[2] Bai Jie. Internet thinking and ideological and political education in the work of the integration of 
research [J]. Journal of University of Electronic Science and Technology, 2017 (02).

[3] Sun Lixia, A Niuquhamo. The ideological and political work reform from the media age of the students who born after "95" [J]. Education and occupation, 2016 (17): 49-51. 